\title{
On the Spheroidized Carbide Dissolution and Elemental Partitioning in High Carbon Bearing Steel 100Cr6
}

\author{
WENWEN SONG, PYUCK-PA CHOI, GERHARD INDEN, ULRICH PRAHL, \\ DIERK RAABE, and WOLFGANG BLECK
}

\begin{abstract}
We report on the characterization of high carbon bearing steel $100 \mathrm{Cr} 6$ using electron microscopy and atom probe tomography in combination with multi-component diffusion simulations. Scanning electron micrographs show that around $14 \mathrm{vol}$ pct spheroidized carbides are formed during soft annealing and only $3 \mathrm{vol}$ pct remain after dissolution into the austenitic matrix through austenitization at $1123 \mathrm{~K}\left(850^{\circ} \mathrm{C}\right)$ for 300 seconds. The spheroidized particles are identified as $(\mathrm{Fe}, \mathrm{Cr})_{3} \mathrm{C}$ by transmission electron microscopy. Atom probe analysis reveals the redistribution and partitioning of the elements involved, i.e., $\mathrm{C}, \mathrm{Si}, \mathrm{Mn}, \mathrm{Cr}, \mathrm{Fe}$, in both, the spheroidized carbides and the bainitic matrix in the sample isothermally heat-treated at $773 \mathrm{~K}$ $\left(500{ }^{\circ} \mathrm{C}\right)$ after austenitization. Homogeneous distribution of $\mathrm{C}$ and a $\mathrm{Cr}$ gradient were detected within the spheroidized carbides. Due to its limited diffusivity in $(\mathrm{Fe}, \mathrm{Cr})_{3} \mathrm{C}, \mathrm{Cr}$ exhibits a maximum concentration at the surface of spheroidized carbides (16 at. pct) and decreases gradually from the surface towards the core down to about 2 at. pct. The atom probe results also indicate that the partially dissolved spheroidized carbides during austenitization may serve as nucleation sites for intermediate temperature cementite within bainite, which results in a relatively softer surface and harder core in spheroidized particles. This microstructure may contribute to the good wear resistance and fatigue properties of the steel. Good agreement between DICTRA simulations and experimental composition profiles is obtained by an increase of mobility of the substitutional elements in cementite by a factor of five, compared to the mobility in the database MOBFE2.
\end{abstract}

DOI: $10.1007 / \mathrm{s} 11661-013-2048-5$

(c) The Minerals, Metals \& Materials Society and ASM International 2013

\section{INTRODUCTION}

Controlling precipitation in steels for enhancing their wear resistance and fatigue properties has been a subject of intense and long-lasting research employing a variety of advanced experimental and modeling approaches. ${ }^{[1-14]} 100 \mathrm{Cr} 6$ steels with the basic composition of 1 wt pet $\mathrm{C}$ and $1.5 \mathrm{wt}$ pet $\mathrm{Cr}$ are among the most extensively used materials for mechanically highly stressed bearings in multiple critical applications in the fields of mobility, safety, manufacturing, mining, and energy infrastructures. As these materials encounter substantial thermomechanical loading in service, the material and heat treatment design should meet the requirements of high fatigue and wear resistance as well as an outstanding combination of strength and toughness.

WENWEN SONG, Scientific Staff, ULRICH PRAHL, Material Simulation Group Leader, and WOLFGANG BLECK, Head, are with the Department of Ferrous Metallurgy, RWTH Aachen University, Aachen, Germany. Contact e-mail: song@iehk.rwth-aachen.de PYUCK-PA CHOI, Atom Probe Tomography Research Group Leader, GERHARD INDEN, Professor, and DIERK RAABE, Chief Executive, are with the Max-Planck-Institut für Eisenforschung $\mathrm{GmbH}$, Düsseldorf, Germany.

Manuscript submitted March 6, 2013.

Article published online October 30, 2013
A special soft annealing treatment, hereafter also referred to as spheroidization heat treatment, produces a mixed microstructure of relatively coarse spheroidized cementite particles embedded in ferrite, which facilitates machining, as well as warm and cold forming of the steel. This microstructure can be subjected to further heat treatment to achieve a final martensitic or bainitic microstructure. Spheroidization kinetics has been long known to be influenced both, by carbon and chromium diffusion and by their respective concentration values. Higher carbon concentration promotes the spheroidization process, because it provides a higher number density of nucleation sites. Chromium reduces the inter-lamellar spacing of pearlite, which is often the starting structure for spheroidization. ${ }^{[15]}$ Spheroidization in $100 \mathrm{Cr} 6$ bearing steel has great influence on the subsequent bainitic and pearlitic transformation. By varying the spheroidization process parameters, namely the holding time and temperature, the dissolution kinetics can be controlled. In this way, the desired content of spheroidized carbides and the distribution of carbon content in both spheroidized carbides and ferrite can be achieved.

In the present work, we characterized the spheroidized carbides with respect to the morphology, crystallography, phase fraction, size distribution, transformation kinetics, and near atomic-scale chemical gradients of different elements using electron microscopy and atom probe tomography (APT) in combination with multicomponent diffusion simulations (DICTRA). APT was 
Table I. Chemical Composition of the Investigated Steel 100Cr6

\begin{tabular}{lcccccccrrrr}
\hline Element & $\mathrm{C}$ & $\mathrm{Si}$ & $\mathrm{Mn}$ & $\mathrm{P}$ & $\mathrm{S}$ & $\mathrm{Cr}$ & $\mathrm{Mo}$ & $\mathrm{Ni}$ & $\mathrm{Cu}$ & $\mathrm{Al}$ \\
\hline wt pct & 0.967 & 0.30 & 0.23 & 0.003 & $<0.001$ & 1.38 & 0.02 & 0.07 & 0.05 & 0.026 \\
at. pct & 4.325 & 0.58 & 0.23 & 0.005 & $<0.002$ & 1.43 & 0.01 & 0.07 & 0.04 & 0.052 \\
\hline
\end{tabular}

employed to study the elemental distributions in spheroidized carbides and bainite. ${ }^{[16]}$ The partitioning behavior of carbon and other alloy elements across the phase boundaries are discussed, with an emphasis on the effect of $\mathrm{Cr}, \mathrm{Mn}$, and $\mathrm{Si}$ on the growth kinetics of cementite.

\section{EXPERIMENTAL}

The chemical composition of the 100Cr6 steel studied here is given in Table I. The steel is mainly alloyed with $\mathrm{Cr}$ and microalloyed with $\mathrm{Mo}$. $\mathrm{Si}$ and $\mathrm{Mn}$ contents are at a low level, while the $\mathrm{Al}$ content is almost negligible. The $\mathrm{N}$ content in the steel is $75 \mathrm{ppm}$.

The heat treatment cycle (HTC) and the conditions investigated are illustrated in Table II and Figure 1. After hot forging, the material was soft annealed industrially and cooled down to form a spheroidized microstructure (HTC1). Starting with the spheroidized microstructure, the samples were heated up at a rate of $3.3 \mathrm{~K} / \mathrm{s}$ and austenitized at $1123 \mathrm{~K}\left(850{ }^{\circ} \mathrm{C}\right)$ for $300 \mathrm{sec}-$ onds. After austenitization, two heat treatment routes were performed. One was quenching to room temperature in $\mathrm{Ar}$ (HTC2) and the other was rapidly cooling to $773 \mathrm{~K}\left(500{ }^{\circ} \mathrm{C}\right)$ at a rate of $55 \mathrm{~K} / \mathrm{s}$. At $773 \mathrm{~K}\left(500{ }^{\circ} \mathrm{C}\right)$, the samples were isothermally held for 1200 seconds in order to form a bainitic microstructure (HTC3) with subsequent air cooling. Austenitization and bainitization were performed in a Bähr 805A dilatometer, where the dimension of the specimen was $\Phi 3 \mathrm{~mm} \times 10 \mathrm{~mm}$.

Microstructural characterization was performed using scanning (SEM) and transmission electron microscopy (TEM). TEM studies were done at a Tecnai F20G2. TEM foils were prepared with a twin-jet electro polishing device, using an electrolyte composed of $10 \mathrm{vol}$ pct perchloric acid and 90 vol pet acetic acid, applying a voltage of $58 \mathrm{~V}$. APT specimens were electro-polished with the standard micro-polishing methods. APT analyses were performed using a Local Electrode Atom Probe (Cameca, LEAPTM 3000X HR) system in voltage pulsing mode at a specimen temperature of $\sim 60 \mathrm{~K}$ $\left(-213^{\circ} \mathrm{C}\right)$ and a pulse fraction of 15 pct. ${ }^{[17]}$

In order to interpret and validate the experimental data, thermodynamic calculations were performed using the software Thermo-Calc in conjunction with the database TCFE7 and DICTRA with the mobility database MOBFE2. ${ }^{[18]}$ The thermodynamic software ThermoCalc is based on the CALPHAD method. ${ }^{[19]}$ The DICTRA software is based on the assumption of diffusion controlled reactions and of local equilibrium (LE) at the moving interface, see $e . g .,{ }^{[20-22]}$ The LE requires equal chemical potentials of all elements on either side of the interface. The numerical values of the chemical potentials are defined by the mass balance condition.
Table II. Heat Treatment Conditions (HTC) of $100 \mathrm{Cr} 6$ for Investigation

\begin{tabular}{lc}
\hline HTC No. & Heat Treatment Conditions $(\mathrm{HTC})$ \\
\hline HTC 1 & spheroidization + cooling to room \\
& temperature $(\mathrm{RT})$ \\
HTC 2 & spheroidization + austenitization at \\
& $1123 \mathrm{~K}\left(850^{\circ} \mathrm{C}\right)$ for $300 \mathrm{~s}+$ quenching to \\
& room temperature $(\mathrm{RT})$ in Ar \\
HTC 3 & spheroidization + austenitization at \\
& $1123 \mathrm{~K}\left(850{ }^{\circ} \mathrm{C}\right)$ for $300 \mathrm{~s}+$ isothermal \\
& holding at $773 \mathrm{~K}\left(500{ }^{\circ} \mathrm{C}\right)$ for $1200 \mathrm{~s}+$ \\
& cooling to room temperature $(\mathrm{RT})$ in air \\
\hline
\end{tabular}

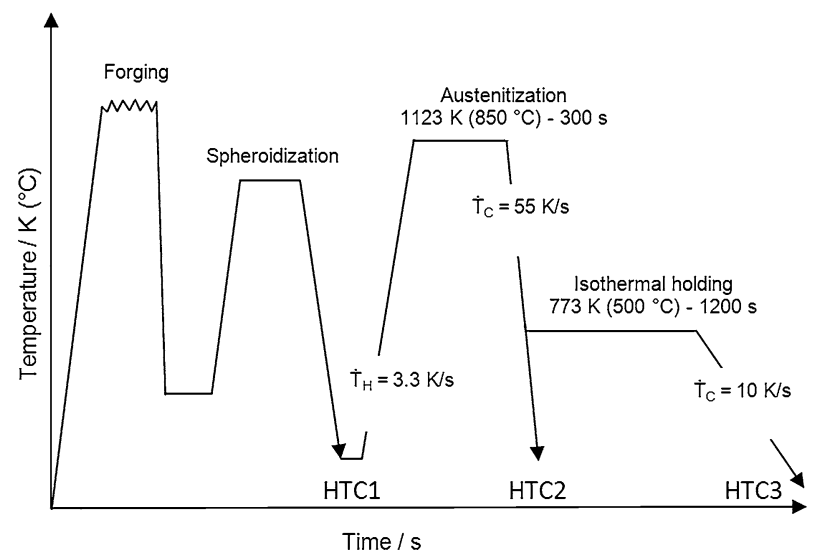

Fig. 1-Heat treatment cycle of the investigated steel $100 \mathrm{Cr} 6$.

\section{RESULTS AND DISCUSSION}

\section{A. Microstructure}

1. Morphology, phase fraction, and size distribution of spheroidized carbides

The microstructures and corresponding spheroidized particle size distributions in 100Cr6 at different heat treatment conditions are shown in Figure 2. Figure 2(a) reveals the ferritic matrix with spheroidized carbides (particles of bright contrast in SEM image) after spheroidization at $1073 \mathrm{~K}\left(800{ }^{\circ} \mathrm{C}\right)$ for 7200 seconds (HTC1). The volume fraction of the spheroidized carbide particles was estimated from the area fraction in the SEM image and was obtained from measurements of 2000 particles for each heat treatment condition. By using metallographic methods (i.e., grinding, polishing, Klemm etching, and following image analysis by contrast), the phase fraction of spheroidized carbides is determined to be 14 vol pct. The corresponding particle size distribution is displayed in Figure 2(b). Due to an incomplete dissolution into austenite, the spheroidized 

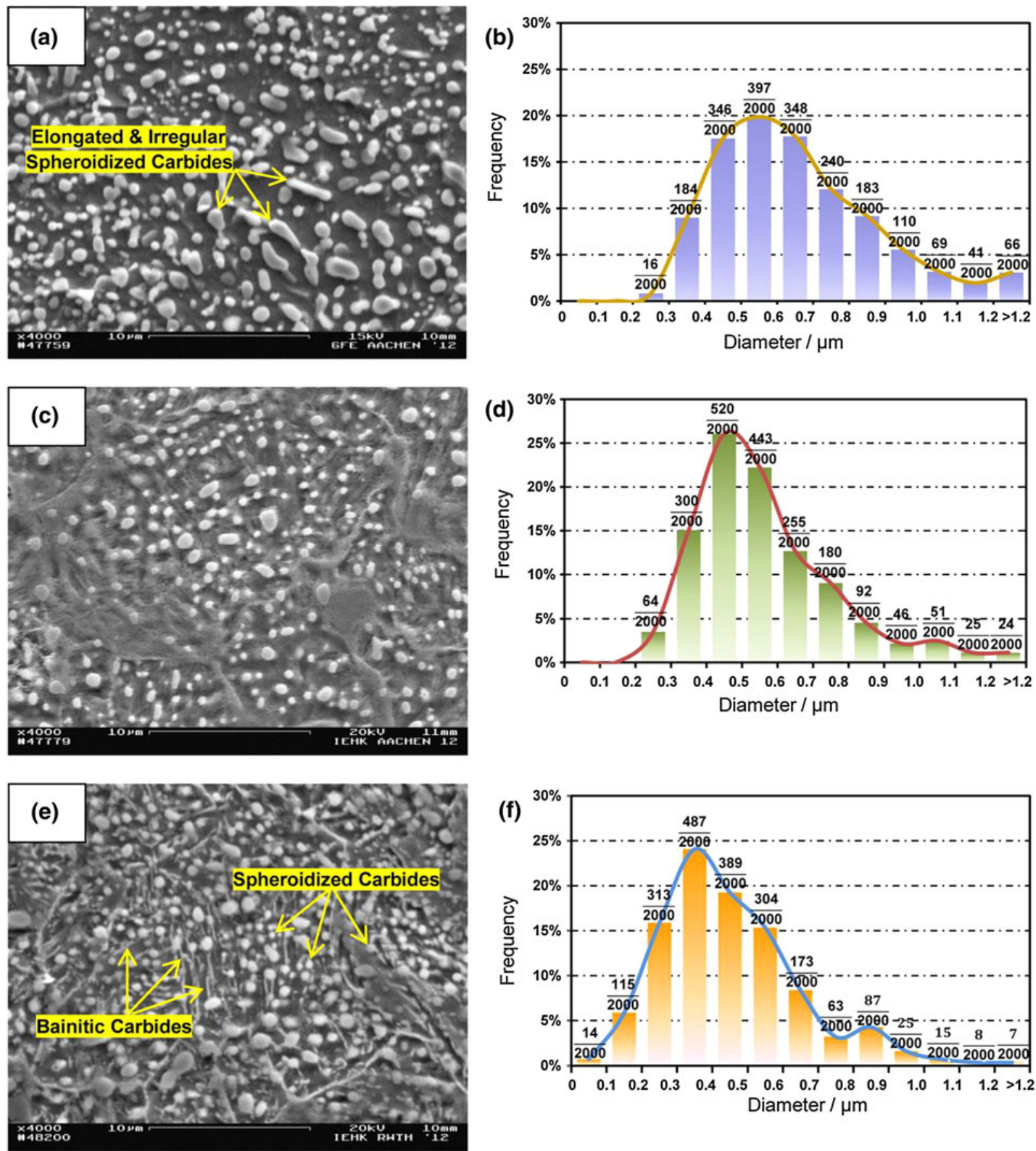

Fig. 2-Microstructure and spheroidized particle size distributions in $100 \mathrm{Cr} 6$ bearing steel after different heat treatments: $(a)$ ferritic matrix with spheroidized carbides under HTCl conditions, $(b)$ size distribution of spheroidized carbides under HTC1 conditions, $(c)$ martensitic matrix with partially dissolved spheroidized carbides under HTC2 conditions, $(d)$ size distribution of partially dissolved spheroidized carbides under HTC2 conditions, $(e)$ bainitic matrix with partially dissolved spheroidized carbides under HTC3 conditions, $(f)$ size distribution of partially dissolved spheroidized carbides under HTC3 conditions (see Table II and Fig. 1).

carbides are distributed inhomogeneously and some of the partially dissolved particles still exhibit elongated and irregular shapes. The spheroidized particles observed in $\mathrm{HTCl}$ condition have an average size of $0.63 \pm 0.02 \mu \mathrm{m}$. After austenitization at $1123 \mathrm{~K}$ $\left(850{ }^{\circ} \mathrm{C}\right.$ ) for 300 seconds (HTC2), most of the spheroidized carbides are dissolved and only 3 vol pct remains. After quenching, the microstructure exhibits a martens- itic matrix with partially dissolved spheroidized carbides (Figure 2(c)). The particles have become more spherical and smaller, with an average size $0.49 \pm 0.02 \mu \mathrm{m}$. After austenitization at $1123 \mathrm{~K}\left(850^{\circ} \mathrm{C}\right)$ for 300 seconds followed by isothermal holding at $773 \mathrm{~K}\left(500{ }^{\circ} \mathrm{C}\right)$ for 1200 seconds (HTC3), the microstructure consists of a bainitic matrix with partially dissolved spheroidized carbides (see Figure 2(e)), where the corresponding 
particle size distribution is displayed in Figure 2(f). As is shown in Figure 2(e), the elongated bainitic carbides within bainitic structure are formed during isothermal holding bainitic transformation in the HTC3 condition. Thus, the total fraction of carbides in bainitic matrix is more than that in martensitic matrix. However, the fraction of the spheroidized carbides in martensitic condition and bainitic condition are the same (Table III). The martensitic matrix and bainitic matrix are determined by both heat treatment process and microstructure features. The martensitic matrix is gained by quenching in He after austenitization at a cooling rate of $55 \mathrm{~K} / \mathrm{s}$. The bainitic matrix is gained by isothermal holding at $773 \mathrm{~K}\left(500^{\circ} \mathrm{C}\right)$ after austenitization. The quenched martensite show twinned plate features without carbides and the bainitic structure show bainitic ferrite lath with bainitic carbides which consists of interlath cementite substructure (Figure 3(a)). The phase fractions and particle sizes of spheroidized carbides determined by metallographic analysis method (i.e., grinding, polishing, Klemm etching, and following image analysis by contrast) are listed in Table III. One can see that after $1123 \mathrm{~K}\left(850^{\circ} \mathrm{C}\right)$ austenitization for 300 seconds followed by isothermal holding at $773 \mathrm{~K}$ $\left(500{ }^{\circ} \mathrm{C}\right)$ for 1200 seconds $(\mathrm{HTC} 3)$, the phase fraction of

Table III. Phase Fractions and Particle Sizes of Partially Dissolved Spheroidized Carbides Under Different Heat Treatment Conditions

\begin{tabular}{|c|c|c|c|}
\hline $\begin{array}{l}\text { Heat } \\
\text { Treatment } \\
\text { Condition } \\
\text { (HTC) }\end{array}$ & HTC1 & HTC2 & HTC3 \\
\hline $\begin{array}{l}\text { Phase } \\
\text { Fraction }\end{array}$ & $14 \mathrm{vol}$ pct & 3 vol pct & 3 vol pct \\
\hline $\begin{array}{c}\text { Particle Size } \\
\text { (Aver. } \\
\text { Diameter) }\end{array}$ & $\begin{array}{l}0.63 \pm \\
\quad 0.02 \mu \mathrm{m}\end{array}$ & $\begin{array}{l}0.49 \pm \\
\quad 0.02 \mu \mathrm{m}\end{array}$ & $\begin{array}{l}0.46 \pm \\
\quad 0.02 \mu \mathrm{m}\end{array}$ \\
\hline
\end{tabular}

the spheroidized carbides remains constant as compared with that in HTC2 condition but the average size of the carbides becomes smaller.

\section{Crystallography and EDX analysis on spheroidized} carbides

Figure 3(a) displays the TEM micrograph of the bainitic microstructure in 100Cr6 obtained after isothermal heat treatment at $773 \mathrm{~K}\left(500{ }^{\circ} \mathrm{C}\right)$ for 1200 seconds (HTC3). During isothermal bainitic transformation at $773 \mathrm{~K}\left(500{ }^{\circ} \mathrm{C}\right)$, upper bainite microstructure is achieved. As is shown in the TEM bright field image in Figure 3(a), inter-lath cementite precipitates between bainitic ferrite laths within bainitic structure. As is mentioned above, 14 vol pct spheroidized carbides already exist before austenitization process (HTC1). During austenitization, the spheroidized carbides dissolve into austenite matrix. And after austenitization and quenching in He, 3 vol pct spheroidized carbides are detected in the steel (Figure 2(c), HTC2). During the following isothermal transformation at $773 \mathrm{~K}\left(500{ }^{\circ} \mathrm{C}\right)$ (HTC3), no further dissolution of spheroidized carbides is expected and the fraction of spheroidized carbides under HTC3 condition maintains the same as that in HTC2 condition (Table III). The partially dissolved spheroidized carbides remain in bainitic matrix. The TEM bright field image (Figure 3(a)) shows inter-lath $\mathrm{Fe}_{3} \mathrm{C}$ precipitates within bainitic structure and partially dissolved spheroidized carbides $(\mathrm{Fe}, \mathrm{Cr})_{3} \mathrm{C}$. The partially dissolved spheroidized carbides are proved to be $(\mathrm{Fe}, \mathrm{Cr})_{3} \mathrm{C}$ with the zone direction of [011] using the method of selected area diffraction (SAD) in Figure 3(b). EDX chemical analysis further indicates the $\mathrm{Cr}$ content within $(\mathrm{Fe}, \mathrm{Cr})_{3} \mathrm{C}$ is about $12 \mathrm{wt}$ pct, as shown in Figure 4 point 4 measurement.

\section{B. Phase Transformation Kinetics}

Figure 5(a) shows the dilatation curve of heating from room temperature at a rate of $3.3 \mathrm{~K} / \mathrm{s}$ to $1123 \mathrm{~K}\left(850{ }^{\circ} \mathrm{C}\right)$

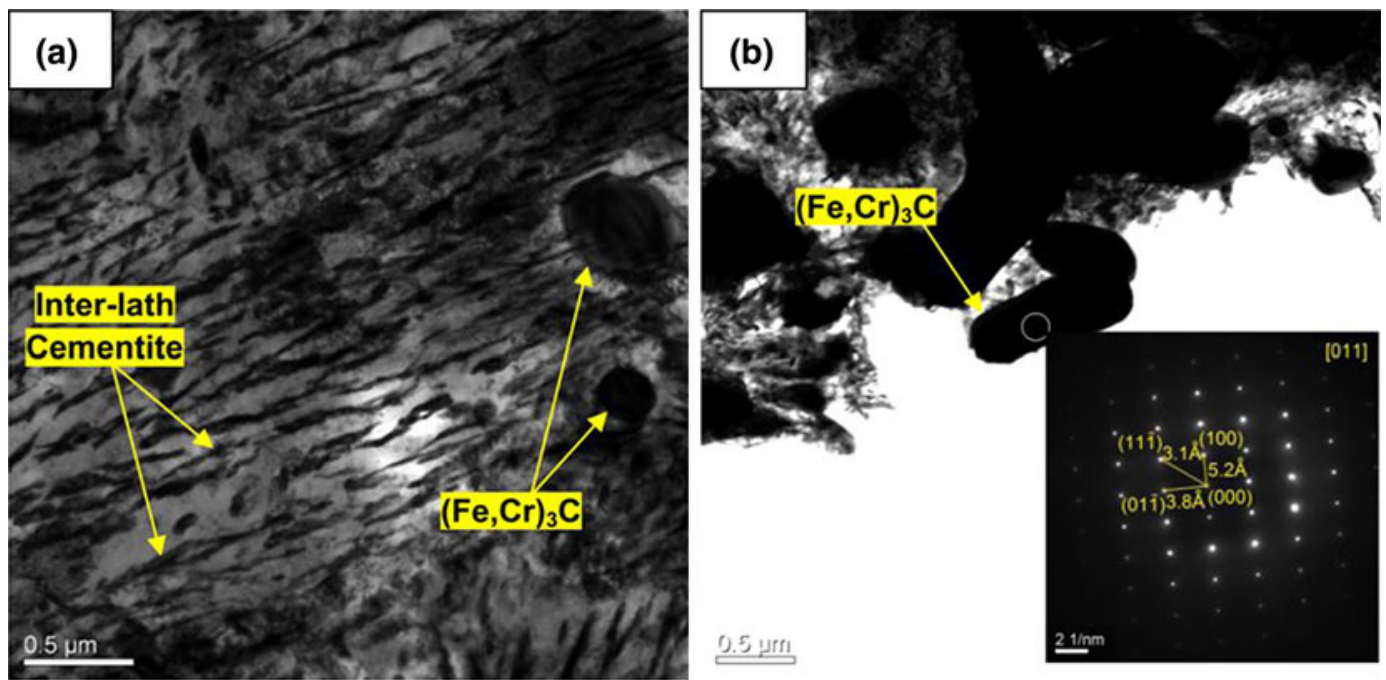

Fig. 3-(a) TEM bright field image showing the inter-lath $\mathrm{Fe}_{3} \mathrm{C}$ precipitation within bainitic structure and partially dissolved spheroidized carbide $(\mathrm{Fe}, \mathrm{Cr})_{3} \mathrm{C}$ in $100 \mathrm{Cr} 6$ isothermally heat treatment at $773 \mathrm{~K}\left(500^{\circ} \mathrm{C}\right)$ for $1200 \mathrm{~s}(\mathrm{HTC} 3$, see Table II and Fig. 1); (b) Selected area diffraction (SAD) pattern showing partially dissolved spheroidized carbide $(\mathrm{Fe}, \mathrm{Cr})_{3} \mathrm{C}$ corresponding to [011] zone axis. 

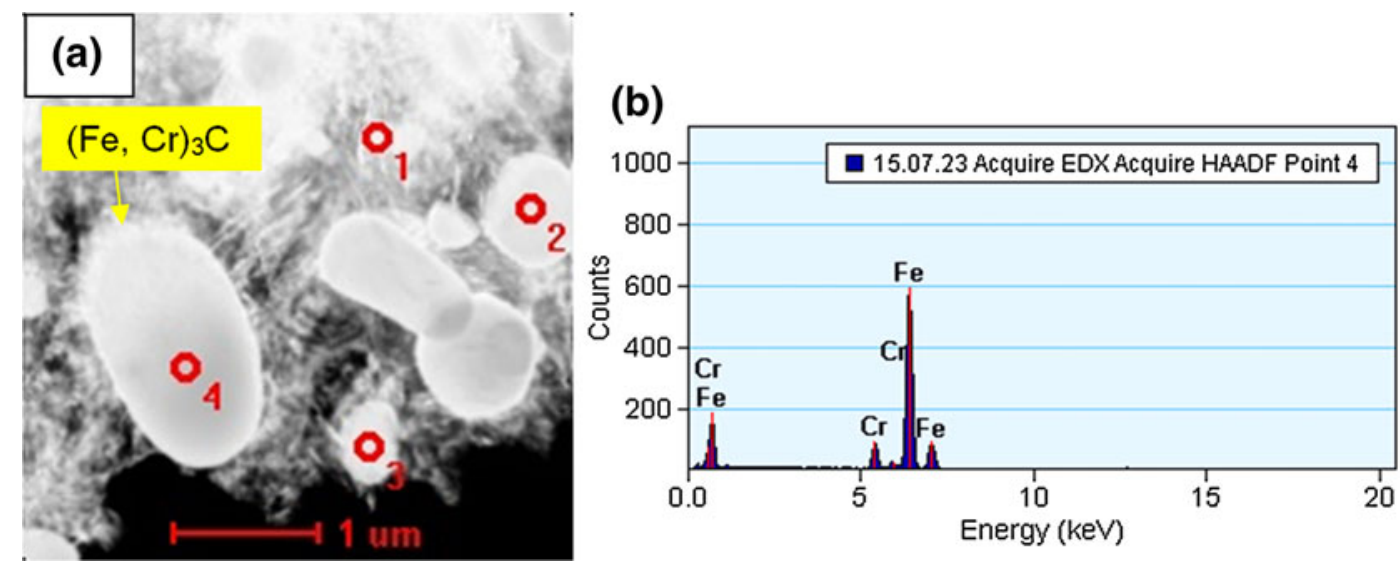

Fig. 4 - (a) STEM image showing partially dissolved spheroidized carbide ( $\mathrm{Fe}, \mathrm{Cr})_{3} \mathrm{C}$ in $100 \mathrm{Cr} 6$; (b) EDX chemical analysis at point 4 in (a).

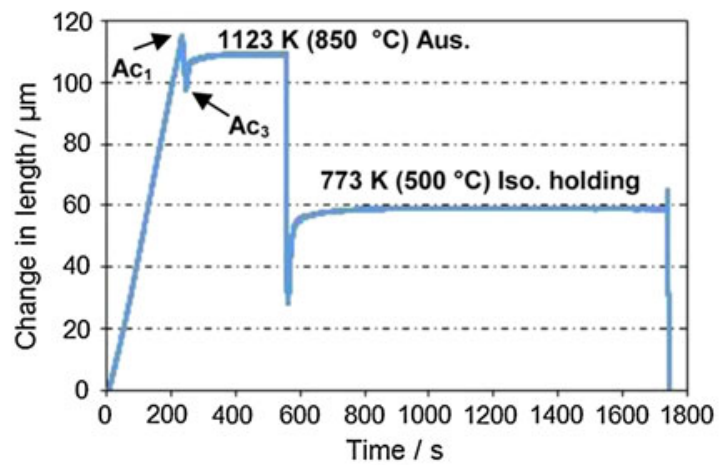

(a)

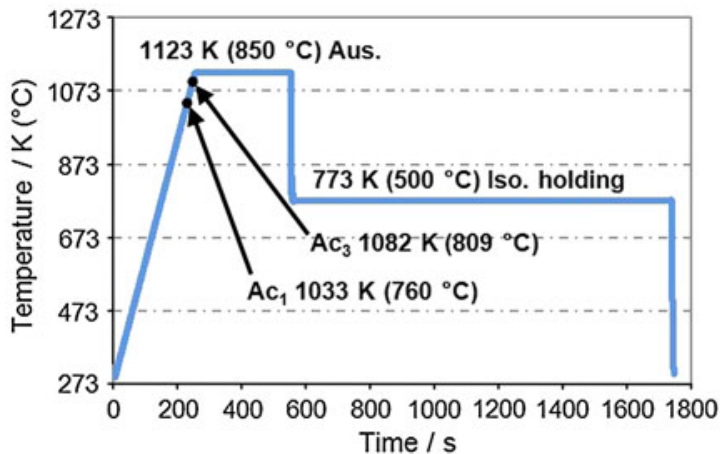

(c)

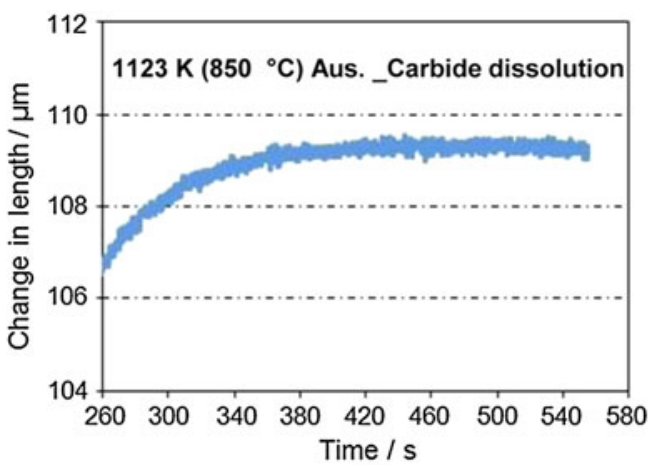

(b)

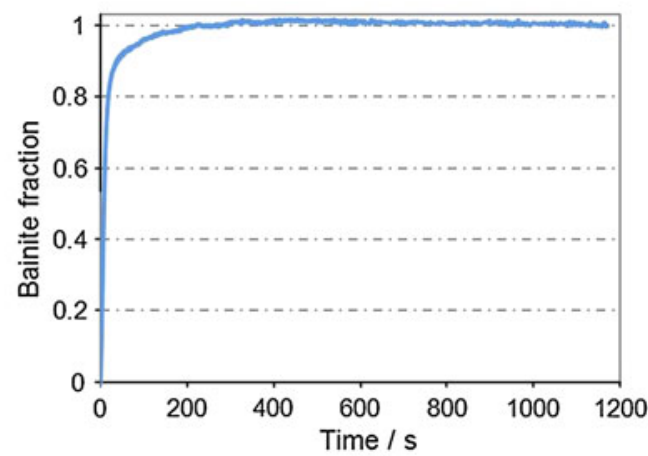

(d)

Fig. 5-(a) Change in length vs transformation time in 100Cr6 along the heat treatment cycle HTC3; (b) spheroidized carbide dissolution during austenitization at $1123 \mathrm{~K}\left(850^{\circ} \mathrm{C}\right) ;(c)$ time-temperature profile of the phase transformations in $100 \mathrm{Cr} 6$ along the heat treatment cycle $\mathrm{HTC} 3$; (d) kinetics curve of isothermal bainitic transformation in $100 \mathrm{Cr} 6$ at $773 \mathrm{~K}\left(500{ }^{\circ} \mathrm{C}\right)$ for $1200 \mathrm{~s}(\mathrm{HTC} 3)$

austenitization for 300 seconds followed by isothermal holding at $773 \mathrm{~K}\left(500{ }^{\circ} \mathrm{C}\right)$ for 1200 seconds (HTC3). Ferrite dissolution starting temperature $\mathrm{Ac}_{1}$ is determined to be about $1033 \mathrm{~K}\left(760{ }^{\circ} \mathrm{C}\right)$ and its finishing temperature $\mathrm{Ac}_{3}$ is at $1082 \mathrm{~K}\left(809^{\circ} \mathrm{C}\right)$. Ferrite dissolution occurs quite fast which just experiences few seconds and this leads to the decrease of length. As shown in Figure 5(b), the length increases as a result of spheroidized carbide dissolution during austenitization at $1123 \mathrm{~K}\left(850^{\circ} \mathrm{C}\right)$. The carbide dissolution rate is higher in the first few minutes and becomes slow gradually. In this process, both $\mathrm{Cr}$ and $\mathrm{C}$ diffusion play important roles. As is shown in the time-temperature profile of the phase transformations in $100 \mathrm{Cr} 6$ along the heat treatment cycle HTC3 in Figure 5(c), ferrite dissolution is finished during heating process before austenitization at $1123 \mathrm{~K}\left(850^{\circ} \mathrm{C}\right)$. Isothermal bainitic transformation at $773 \mathrm{~K}\left(500^{\circ} \mathrm{C}\right)$ occurs quite fast at the first stage. Within the first 40 seconds, 90 pct bainite is formed. The incubation time is below 1 second which means that almost no incubation time is required for isothermal bainitic transformation in $100 \mathrm{Cr} 6$ at $773 \mathrm{~K}\left(500^{\circ} \mathrm{C}\right)$. 

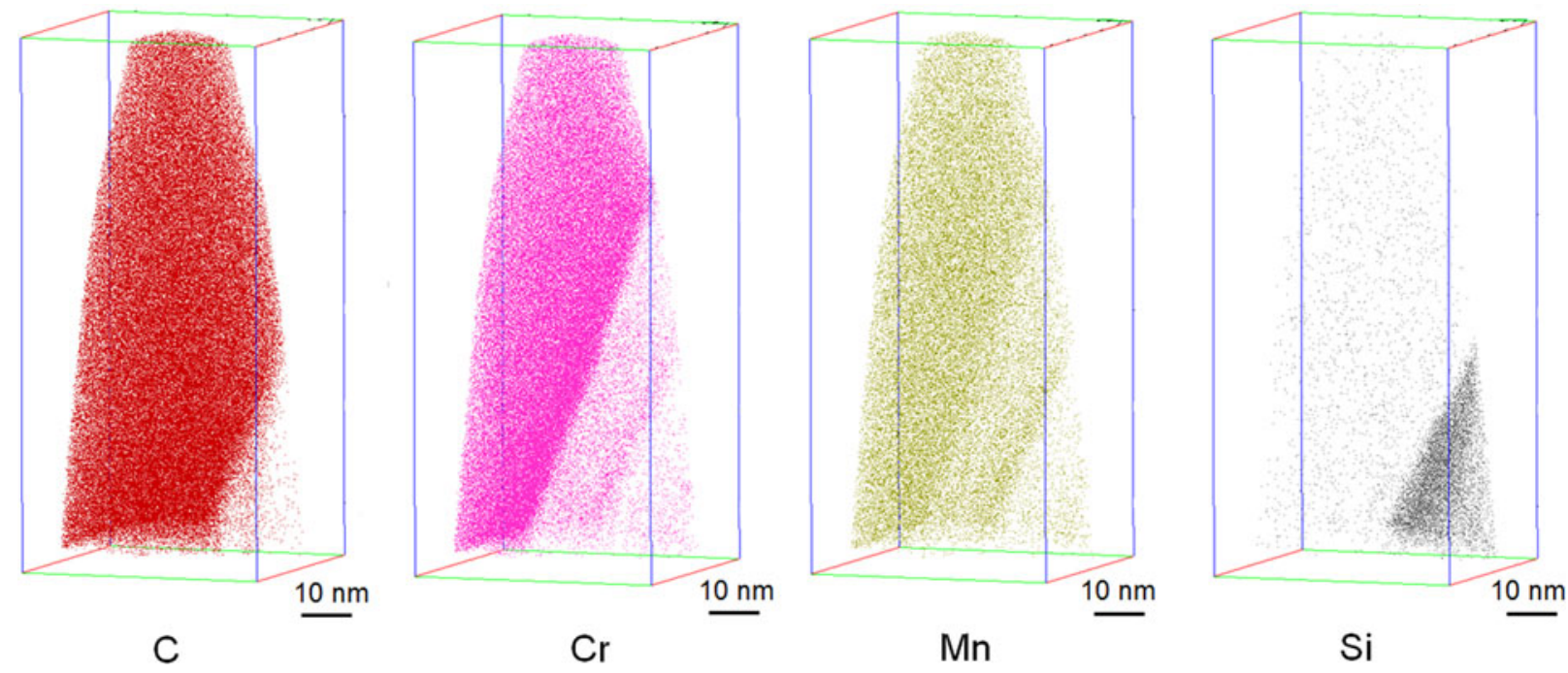

Fig. 6-3-Dimensional atom maps obtained from the investigated material isothermally heat treated at $773 \mathrm{~K}\left(500{ }^{\circ} \mathrm{C}\right)$ for $1200 \mathrm{~s}(\mathrm{HTC} 3)$.

\section{Atom Probe Tomography (APT)}

$3 \mathrm{D}$ atom maps obtained from the material isothermally heat treatment at $773 \mathrm{~K}\left(500{ }^{\circ} \mathrm{C}\right)$ for 1200 seconds (HTC3) are shown in Figure 6. The distribution of the carbon and alloy element atoms in the analysis volume is clearly non-uniform. Enrichment and depletion zones of $\mathrm{C}, \mathrm{Cr}, \mathrm{Mn}$, and $\mathrm{Si}$ can be recognized in the corresponding elemental maps.

As shown in Figure 7, carbon atoms are distributed homogeneously in both, the partially dissolved spheroidized carbide $(\mathrm{Fe}, \mathrm{Cr})_{3} \mathrm{C}$ and in the newly formed cementite. Carbon atoms exhibit a clear transition between cementite and bainitic ferrite. Due to the low solubility of carbon in ferrite, $\alpha_{\mathrm{B}}$ is depleted of carbon. In contrast, $\mathrm{Si}$ is mostly dissolved in the bainitic ferrite matrix and shows quite low solubility in cementite. Mn and $\mathrm{Cr}$ exhibit the same solute characteristics in partially dissolved spheroidized carbide $(\mathrm{Fe}, \mathrm{Cr})_{3} \mathrm{C}$, newly formed cementite at $773 \mathrm{~K}\left(500{ }^{\circ} \mathrm{C}\right)$ and bainitic ferrite matrix. Due to the fact that $\mathrm{Cr}$ and $\mathrm{Mn}$ have higher diffusivity and higher solubility in $\mathrm{Fe}_{3} \mathrm{C}$ at high temperature, i.e., austenitization at $1123 \mathrm{~K}\left(850^{\circ} \mathrm{C}\right), \mathrm{Cr}$ and $\mathrm{Mn}$ atoms show a higher enrichment in spheroidized carbide $(\mathrm{Fe}, \mathrm{Cr})_{3} \mathrm{C}$ than in newly formed cementite at $773 \mathrm{~K}\left(500{ }^{\circ} \mathrm{C}\right)$ and the smallest concentration in bainitic ferrite.

Figure 8 illustrates the 1D concentration profile (along the cylindrical region of interest in Figure 7) showing the distribution of different elements, i.e., C, Si, $\mathrm{Cr}$, and $\mathrm{Mn}$ in partially dissolved spheroidized carbide $(\mathrm{Fe}, \mathrm{Cr})_{3} \mathrm{C}$ and in newly formed cementite at $773 \mathrm{~K}$ $\left(500{ }^{\circ} \mathrm{C}\right)$ in contact with the bainitic ferrite matrix. The results in Figure 8(a) show a homogeneous distribution of the fast-diffusing element $\mathrm{C}$, both in partially dissolved spheroidized carbides and in newly formed cementite during the isothermal holding process at $773 \mathrm{~K}\left(500{ }^{\circ} \mathrm{C}\right)$. Cr exhibits a gradual chemical gradient in the spheroidized carbides. The $\mathrm{Cr}$ concentration shows a maximum at the surface (16 at. pct), gradually decreasing from the surface to the center in spheroidized carbides. Across the interface between partially dissolved spheroidized carbide $(\mathrm{Fe}, \mathrm{Cr})_{3} \mathrm{C}$ and newly formed bainitic $\mathrm{Fe}_{3} \mathrm{C}$, the $\mathrm{Cr}$ concentration shows a sharp decrease. This effect is attributed to the different solubility of $\mathrm{Cr}$ in austenite and ferrite as well as to the different diffusivity values for $\mathrm{Cr}$ at the austenitization temperature of $1123 \mathrm{~K}\left(850{ }^{\circ} \mathrm{C}\right)$ and at the bainitic transformation temperature of $773 \mathrm{~K}\left(500{ }^{\circ} \mathrm{C}\right)$. At $773 \mathrm{~K}\left(500{ }^{\circ} \mathrm{C}\right), \mathrm{Cr}$ has a very low diffusivity in bainitic ferrite which means that this element is essentially frozen in. Tables IV, V show the composition of cementite in equilibrium with ferrite and the diffusivities in cementite, ferrite, and austenite. The diffusivity data for ferrite and austenite correspond to the nominal composition given in Table I, which is reasonable since the precipitation reactions we discuss start always with a matrix fec or bec with the nominal composition. The data are derived from thermodynamic calculations using the software Thermo-Calc with the database TCFE7 and DICTRA with the mobility database MOBFE2.

Figure 8(b) represents the magnified curves of concentration profiles in a selected part of Figure 8(a). The partitioning characteristics of carbon and other alloying elements across the bainitic ferrite $\left(\alpha_{\mathrm{B}}\right) /$ cementite interface are revealed in Figure 8(b). The carbon partitions according to the LE between bainitic ferrite $\left(\alpha_{\mathrm{B}}\right)$ and cementite, while the substitutional elements $\mathrm{Cr}, \mathrm{Mn}$, and $\mathrm{Si}$ redistribute over a short range and exhibit enrichment at the $\alpha_{\mathrm{B}} / \theta$ interface. Si is mostly dissolved in the bainitic ferrite matrix and exhibits a relatively low solubility in cementite. Figure 8(b) shows that $\mathrm{Si}$ is highly enriched at the interface between the bainite and the cementite, which kinetically impedes the further growth of cementite. The data also reveal that there is no long range redistribution of the substitutional elements $\mathrm{Cr}$, Mn, and $\mathrm{Si}$. The various interstitial and substitutional elemental partitioning features in the current APT investigation infer that 


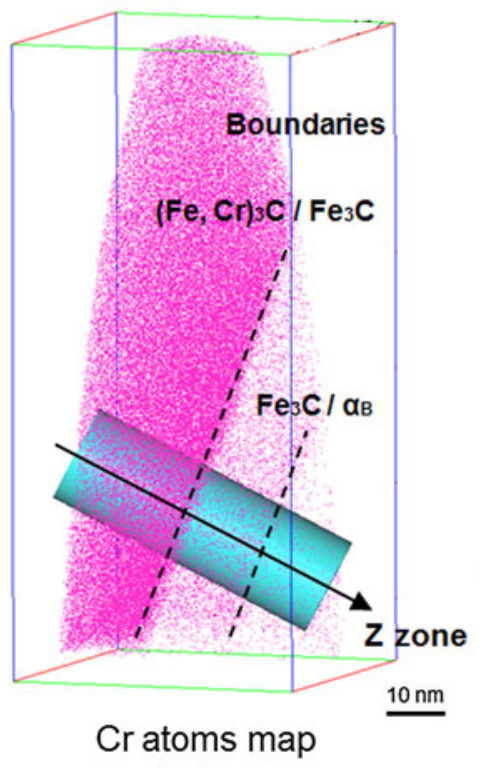

(a)

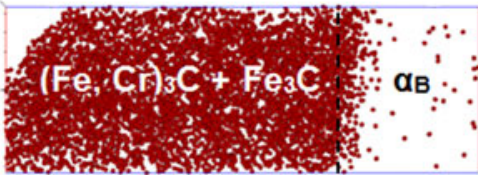

C

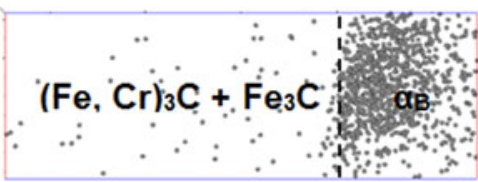

$\mathrm{Si}$

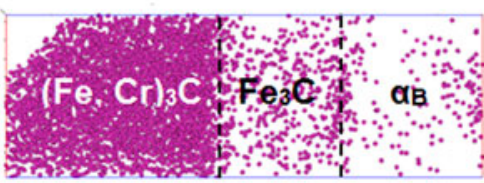

$\mathrm{Cr}$

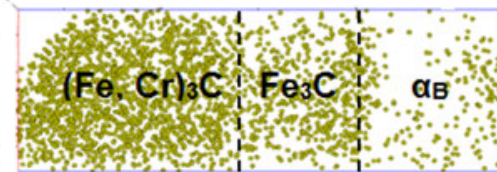

$\mathrm{Mn}$

(b)

Fig. 7- (a) 3-Dimensional map of $\mathrm{Cr}$ atoms; $(b)$ the selected box from (a) showing the $\mathrm{C}, \mathrm{Si}, \mathrm{Cr}$, and $\mathrm{Mn}$ distributions; $(\mathrm{Fe}, \mathrm{Cr})_{3} \mathrm{C}$ is partially dissolved spheroidized carbide, $\mathrm{Fe}_{3} \mathrm{C}$ is the newly formed bainitic cementite.

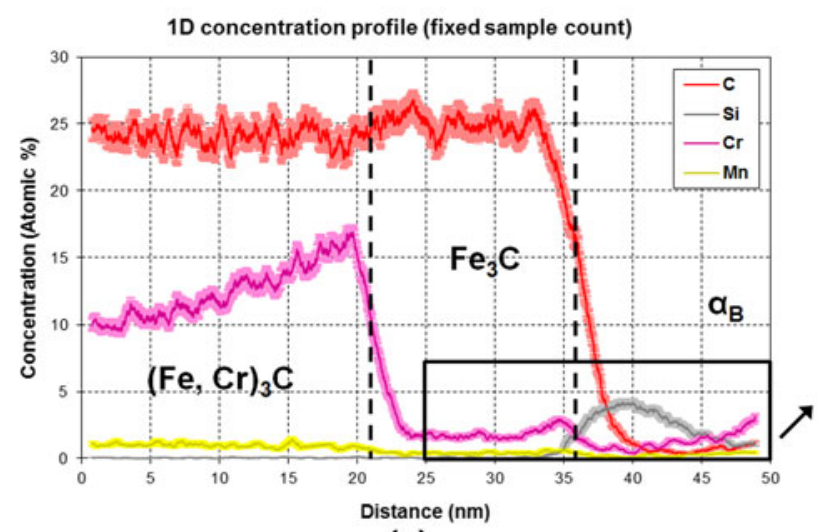

(a)

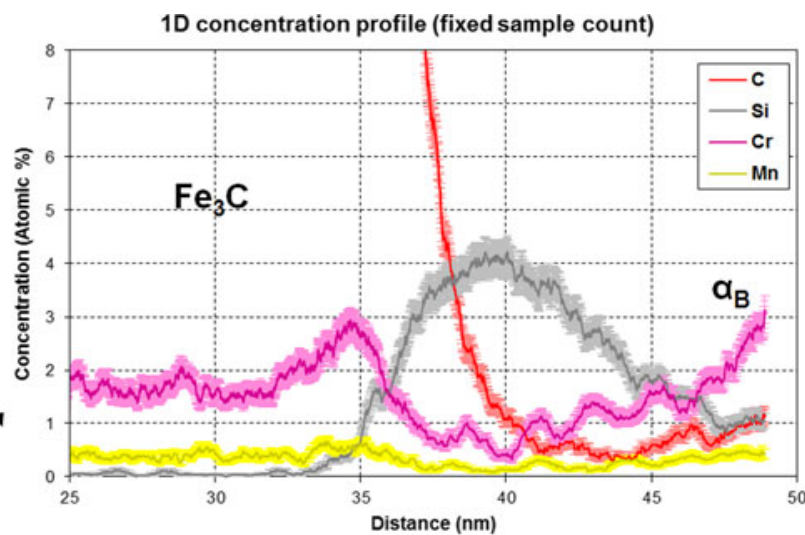

(b)

Fig. 8-1-Dimensional concentration profile (fixed sample count) showing the distribution of $\mathrm{C}, \mathrm{Si}, \mathrm{Cr}, \mathrm{Mn}$ in partially dissolved spheroidized carbide $(\mathrm{Fe}, \mathrm{Cr})_{3} \mathrm{C}$, newly formed cementite at $773 \mathrm{~K}\left(500{ }^{\circ} \mathrm{C}\right)$ and bainitic ferrite matrix, which is obtained from the investigated material isothermally heat treated at $773 \mathrm{~K}\left(500{ }^{\circ} \mathrm{C}\right)$ for $1200 \mathrm{~s}(\mathrm{HTC} 3) ;(b)$ represents the magnified curves of concentration profiles in the selected area in $(a)$.

Table IV. Composition of Cementite (Mole Fractions) in Equilibrium with Ferrite at $773 \mathrm{~K}\left(500{ }^{\circ} \mathrm{C}\right)$ and Austenite at $1123 \mathrm{~K}\left(850{ }^{\circ} \mathrm{C}\right)$

\begin{tabular}{lccc}
\hline Temperature $\left[\mathrm{K}\left({ }^{\circ} \mathrm{C}\right)\right]$ & $x(\mathrm{Cr})$ & $x(\mathrm{Mn})$ & $x(\mathrm{Si})$ \\
\hline $773(500)$ & 0.07813 & 0.01106 & $10^{-12}$ \\
$1123(850)$ & 0.09903 & 0.00333 & $6 \times 10^{-12}$ \\
\hline
\end{tabular}

cementite precipitate in upper bainite under negligible partitioning local equilibrium (NPLE) mode. Moreover, cementite precipitates under a different mode during lower bainite formation. Our previous results on this material obtained using $\mathrm{APT}^{[23]}$ reveals that cementite precipitates under NPLE mode in upper bainite at $773 \mathrm{~K}\left(500{ }^{\circ} \mathrm{C}\right)$ and $\varepsilon$ carbide and cementite precipitate under paraequilibrium mode at $533 \mathrm{~K}$ $\left(260{ }^{\circ} \mathrm{C}\right)$ during lower bainite formation. Barrow and Rivera $^{[24]}$ investigated the cementite formation during bainite reaction at a low transformation temperature [about $503 \mathrm{~K}\left(230^{\circ} \mathrm{C}\right)$ ] by means of energy-dispersive spectroscopy and also reported that cementite formation during bainite reaction takes place under paraequilibrium at this low transformation temperature.

Figure 8 indicates that the partially dissolved spheroidized carbides during $1123 \mathrm{~K}\left(850^{\circ} \mathrm{C}\right)$ austenitization 
Table V. Diffusion Coefficient $\left(\mathrm{m}^{2} / \mathrm{s}\right)$

\begin{tabular}{lcccr}
\hline Phase & Temperature $\left[\mathrm{K}\left({ }^{\circ} \mathrm{C}\right)\right]$ & $\mathrm{C}$ & $\mathrm{Cr}$ & $\mathrm{Mn}$ \\
\hline Cementite & $773(500)$ & & $8.27 \mathrm{e}-25$ & $4.96 \mathrm{e}-25$ \\
Cementite & $1123(850)$ & & $8.72 \mathrm{e}-19$ & $5.23 \mathrm{e}-19$ \\
Ferrite & $773(500)$ & $2.35 \mathrm{e}-12$ & $1.87 \mathrm{e}-22$ & $2.20 \mathrm{e}-21$ \\
Ferrite & $1123(850)$ & $3.72 \mathrm{e}-10$ & $1.68 \mathrm{e}-15$ & $3.32 \mathrm{e}-15$ \\
Austenite & $1123(850)$ & $7.06 \mathrm{e}-12$ & $8.01 \mathrm{e}-18$ & $1.18 \mathrm{e}-17$ \\
\hline
\end{tabular}

may serve as nucleation sites for intermediate temperature cementite and grow by the formation of a low $\mathrm{Cr}$ content cementite layer during $773 \mathrm{~K}\left(500{ }^{\circ} \mathrm{C}\right)$ bainitic isothermal holding process, which shows a relatively softer surface and harder inner part in the spheroidized particles. This sophisticated microstructure may lead to a better wear resistance and fatigue properties.

\section{DICTRA Simulations}

In the case of systems with fast-diffusing interstitial elements like $\mathrm{C}$, the local equilibrium may define two different growth regimes: a fast reaction with NPLE or a slow reaction with partitioning of all elements (LE). In the case of one substitutional sublattice (e.g., in ferrite, austenite, cementite) the fraction of component $i$ on the sublattice is denominated u-fraction. In terms of the number $N_{i}$ of atoms of type $i$, or in terms of the mole fraction $x_{i}$, the $\mathrm{u}$-fractions are given by $u_{i}=\frac{N_{i}}{\sum N_{i}}=$ $\frac{x_{i}}{1-x_{C}}$. The NPLE tie-line is defined by the new ${ }^{j \neq}$ hitase $^{N_{j}}$ exhibiting the same u-fraction of substitutional elements as the matrix. There is a strict thermodynamic condition for the NPLE reaction to be possible. If the amount of interstitial element is lower in the new phase than in the matrix (e.g., formation of ferrite from austenite) the activity of the interstitial component in the new phase must be higher than in the matrix, so that the interstitial component is transported into the matrix phase. In the opposite case, e.g., the formation of cementite from ferrite, the $\mathrm{C}$-activity within cementite with the same ufraction of substitutional elements as the ferritic matrix must be lower than in the matrix, leading to a C-flux towards cementite.

In order to keep the diffusion simulations reasonable in time, only the major components $\mathrm{C}, \mathrm{Cr}, \mathrm{Mn}, \mathrm{Si}$ were considered. The calculations were thus performed for the alloy composition $\mathrm{Fe}-1 \mathrm{C}-1.4 \mathrm{Cr}-0.23 \mathrm{Mn}-0.3 \mathrm{Si}$ (wt pct), i.e., Fe-4.468C-1.445Cr-0.2247Mn-0.5733Si (at. pct). The substitutional sublattice composition of ferrite is thus $u(\mathrm{Cr})=0.015126, \quad u(\mathrm{Mn})=0.002352$, $u(\mathrm{Si})=0.006001$. Let us denote by $\mathrm{M}_{3} \mathrm{C}^{*}$ the cementite with the same u-fraction of $\mathrm{Cr}$ and $\mathrm{Mn}$ as the alloy. According to the database TCFE7 cementite dissolves only a negligible amount of $\mathrm{Si}$. The composition of cementite is then $X_{\mathrm{Cr}}=0.011345, X_{\mathrm{Mn}}=0.001764$ $X_{\mathrm{C}}=0.25$. In Table VI, the C-activities of the ferritic matrix and of $\mathrm{M}_{3} \mathrm{C}^{*}$ derived from Dictra calculations are given for the temperature interval from $773 \mathrm{~K}$ to $1073 \mathrm{~K}\left(500{ }^{\circ} \mathrm{C}\right.$ to $\left.800{ }^{\circ} \mathrm{C}\right)$. In all cases, the C-activity at the interface $\mathrm{M}_{3} \mathrm{C}^{*} /$ ferrite is lower than in the ferritic matrix leading to $\mathrm{C}$-diffusion from the matrix towards
Table VI. C-Activities with Reference to Graphite at the Given Temperatures

\begin{tabular}{lcc}
\hline Temperature $\left[\mathrm{K}\left({ }^{\circ} \mathrm{C}\right)\right]$ & $\mathrm{a}_{\mathrm{C}}($ ferrite $)$ & $\mathrm{a}_{\mathrm{C}}\left(\mathrm{M}_{3} \mathrm{C}^{*}\right)$ \\
\hline $1073(800)$ & $2.5247 \mathrm{E}+01$ & $9.3864 \mathrm{E}-01$ \\
$973(700)$ & $8.0311 \mathrm{E}+01$ & $1.2067 \mathrm{E}+00$ \\
$873(600)$ & $3.3301 \mathrm{E}+02$ & $1.7835 \mathrm{E}+00$ \\
$773(500)$ & $1.9950 \mathrm{E}+03$ & $3.0876 \mathrm{E}+00$ \\
\hline
\end{tabular}

Table VII. Composition of the Critical Cementite Nucleus

\begin{tabular}{|c|c|c|c|}
\hline Temperature $\left[\mathrm{K}\left({ }^{\circ} \mathrm{C}\right)\right]$ & $X(\mathrm{Cr})$ & $X(\mathrm{Mn})$ & $X(\mathrm{Si})$ \\
\hline $1073(800)$ & \multicolumn{3}{|c|}{$1.10813 \mathrm{E}-017.02977 \mathrm{E}-037.50000 \mathrm{E}-13$} \\
\hline $973(700)$ & \multicolumn{3}{|c|}{$1.42356 \mathrm{E}-011.16464 \mathrm{E}-027.50000 \mathrm{E}-13$} \\
\hline $873(600)$ & \multicolumn{3}{|c|}{$1.92662 \mathrm{E}-011.95503 \mathrm{E}-027.50000 \mathrm{E}-13$} \\
\hline $773(500)$ & \multicolumn{3}{|c|}{$2.74839 \mathrm{E}-013.16540 \mathrm{E}-027.50000 \mathrm{E}-13$} \\
\hline
\end{tabular}

the carbide. Therefore, the formation of cementite is expected to occur according to the NPLE condition in the whole temperature interval.

The DICTRA simulations were performed assuming a spherical cell with $0.6 \mu \mathrm{m}$ radius. This corresponds to the experimental observation that the average particle diameter is $0.63 \mu \mathrm{m}$ representing $14 \mathrm{vol}$ pct of the total volume. The simulation was started with a cementite nucleus of radius $r=1 \mathrm{~nm}$. The nucleus composition can be obtained from Thermo-calc, see Table VII. This composition can be entered if the particle is defined as present. If the particle is not yet present and forms only after reaching a certain driving force for precipitation, then DICTRA derives this composition automatically. The volume fraction of cementite obtained from DICTRA simulations at $773 \mathrm{~K}, 973 \mathrm{~K}$, and $1073 \mathrm{~K}$ $\left(500{ }^{\circ} \mathrm{C}, 700{ }^{\circ} \mathrm{C}\right.$, and $\left.800{ }^{\circ} \mathrm{C}\right)$ are given in Figure 9 . The most important result of these simulations is the extremely short time of less than one second for the precipitation of cementite. After $0.1 \mathrm{~s}$ cementite has already reached the plateau of its final volume fraction.

The composition profiles in Figure 10 show that the growth of cementite does indeed proceed according to the NPLE reaction with respect to $\mathrm{Cr}$ and $\mathrm{Mn}$. Si cannot be dissolved in cementite. Therefore a spike of $\mathrm{Si}$ is pushed ahead of the moving interface. The height of the spike varies with time and corresponds to LE. Cementite has reached its volume fraction of about 14 vol pct in about 0.1 second. Similar profiles are obtained at $973 \mathrm{~K}$ and $1073 \mathrm{~K}\left(700{ }^{\circ} \mathrm{C}\right.$ and $\left.800{ }^{\circ} \mathrm{C}\right)$. The $\mathrm{Cr}$ - and $\mathrm{Mn}$-content of the growing cementite corresponds to the 
experimental results obtained with APT of the chemical concentration in cementite precipitates.

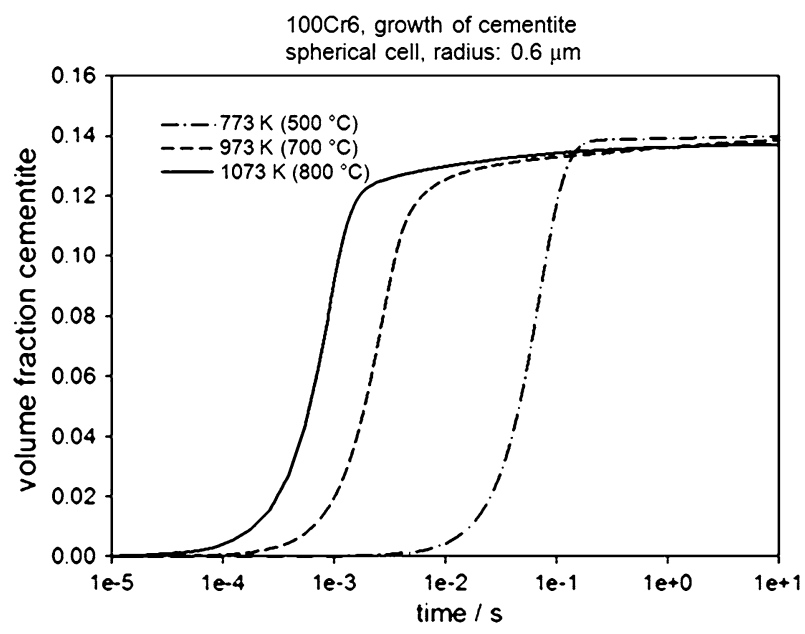

Fig. 9- Growth of cementite in ferrite according to NPLE.

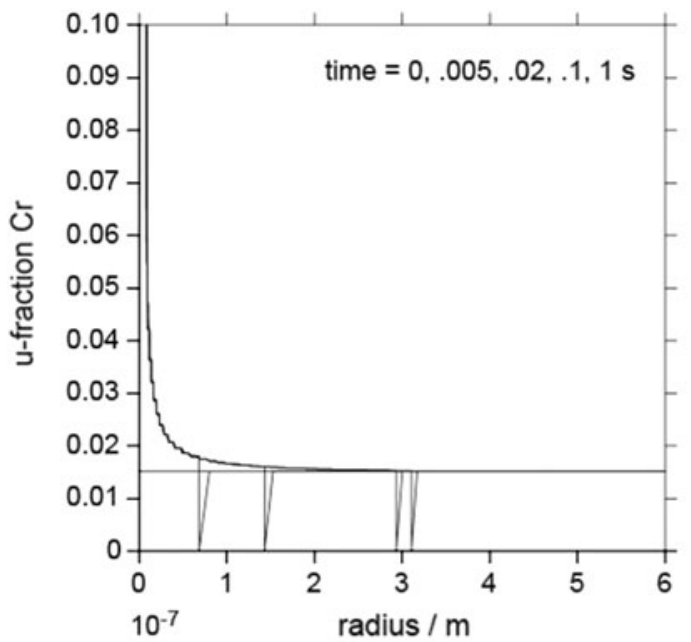

(a)

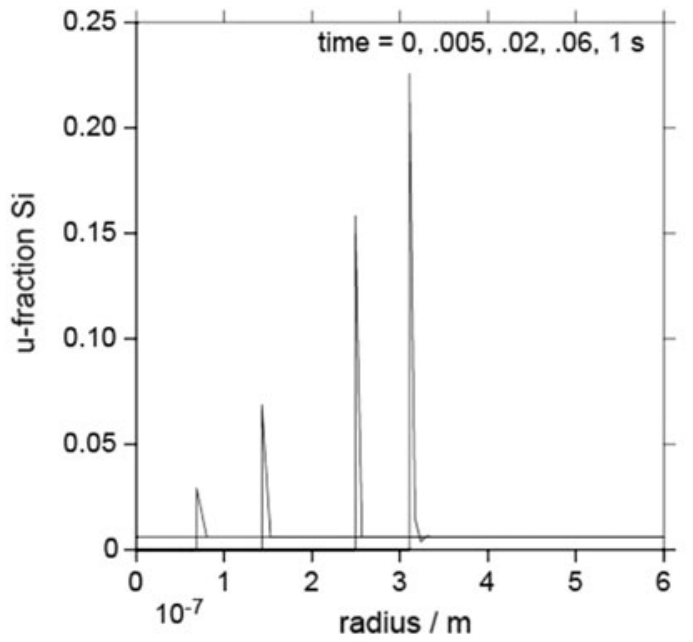

(c)
The results of annealing at $1073 \mathrm{~K}\left(800{ }^{\circ} \mathrm{C}\right)$ for 2 and 5 hours are shown in Figure 11. The experimental results of the austenitization at $1123 \mathrm{~K}\left(850^{\circ} \mathrm{C}\right)$ show that, in order to get good agreement, the mobility of the substitutional elements in cementite has to be increased by a factor of about five compared to the data in MOBFE2. Therefore, in Figure 11 the results for both sets of mobilities are shown. Comparison between Figures 11(a) and (b) already shows that the difference in mobilities creates significantly different composition profiles. The starting configuration of these simulations was cementite formed by the NPLE reaction. This corresponds to the experimental situation with cementite formed during heating or cooling. Due to the NPLE reaction cementite has grown with a much lower $\mathrm{Cr}$ - and Mn-content compared to global equilibrium. Consequently, a reaction towards equilibrium at $1073 \mathrm{~K}$ $\left(800{ }^{\circ} \mathrm{C}\right)$ requires an increase of these elements in cementite. This leads to diffusion of $\mathrm{Cr}$ and $\mathrm{Mn}$ from ferrite into cementite. Si diffuses into the opposite direction and dissolves in ferrite. The Si-spike is completely removed already after about 30 seconds, see

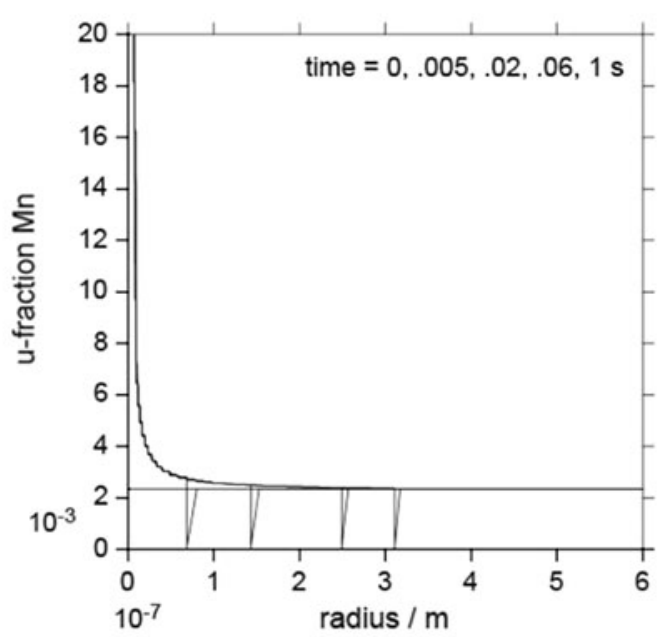

(b)

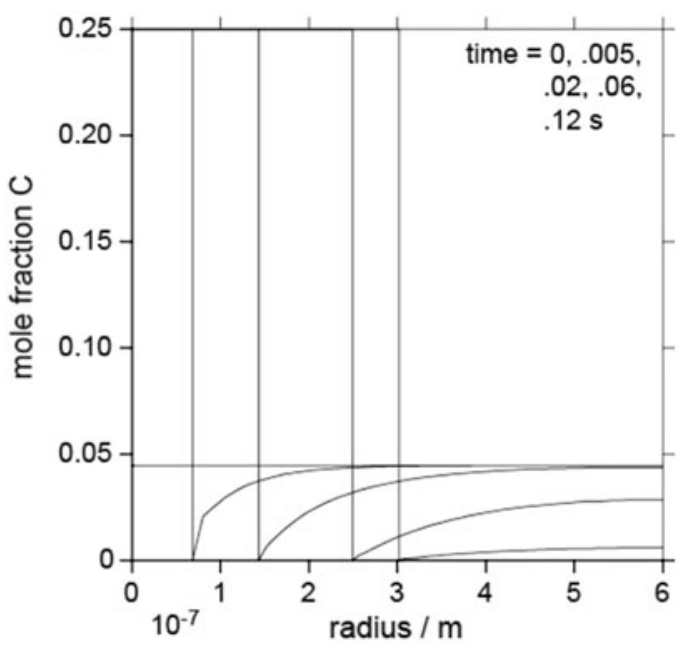

(d)

Fig. 10 - Composition profiles during growth of cementite in ferrite at $773 \mathrm{~K}\left(500^{\circ} \mathrm{C}\right)$ for various time steps. 
Figure 12(b). This is due to the much higher mobility of $\mathrm{Si}$ in ferrite compared to the mobility of substitutional elements in cementite. In conclusion, the treatment at $1073 \mathrm{~K}\left(800{ }^{\circ} \mathrm{C}\right)$ leads to a redistribution of substitutional elements, but there is no further growth within the 2 hours heat treatment.

At $1123 \mathrm{~K}\left(850{ }^{\circ} \mathrm{C}\right)$ ferrite transforms into austenite. The starting $\mathrm{C}$-content in austenite is very low since it is given by that of ferrite at $1073 \mathrm{~K}\left(800{ }^{\circ} \mathrm{C}\right)$. Consequently, cementite dissolves and austenite absorbs the $\mathrm{C}$. In order to simulate this reaction, the starting composition profiles were taken from the result at $1073 \mathrm{~K}$ $\left(800{ }^{\circ} \mathrm{C}\right)$. The composition profiles of the ferrite region at $1073 \mathrm{~K}\left(800{ }^{\circ} \mathrm{C}\right)$ define the composition in the austenite region at $1123 \mathrm{~K}\left(850^{\circ} \mathrm{C}\right)$. The results of the simulation of a treatment at $1123 \mathrm{~K}\left(850^{\circ} \mathrm{C}\right)$ for
300 seconds are shown in Figure 13 for the two cases, mobilities according to MOBFE2 (Figure 13(a)) and increased by a factor of 5 (Figure 13(b)). Figure 14 shows a blow-up of the $\mathrm{Cr}$ content near the interface with a scaling such that a comparison can be made with the experimental data in Figure 8. The result obtained by using the mobility of the database MOBFE2 shows a higher level of $\mathrm{Cr}$ at the interface, a steeper decrease of the Cr-profile within cementite, and a radius of $r=0.268 \mu \mathrm{m}$ which is slightly higher than the experimental average particle size. The results obtained with a change of mobility by a factor of 5 show good agreement with the experimental compositional data measured by APT, and the particle radius after shrinking is $r=0.247 \mu \mathrm{m}$, in excellent agreement with the experimentally observed average particle diameter of

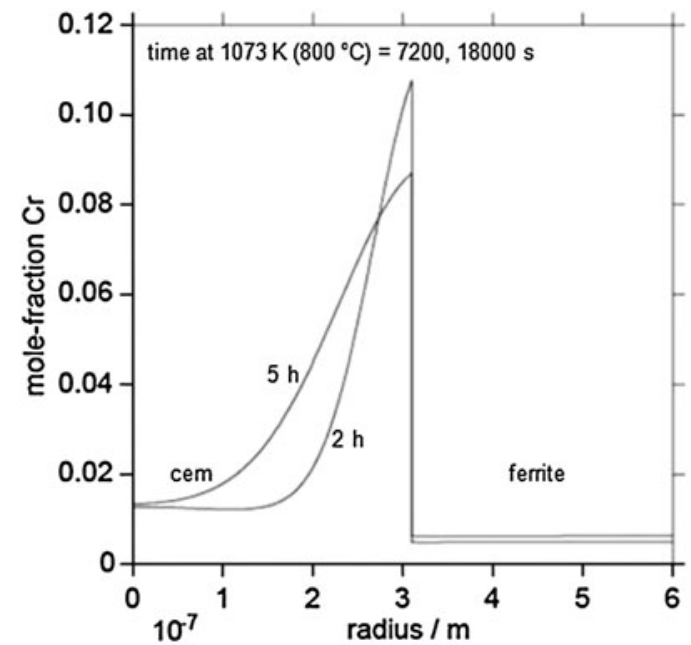

(a)

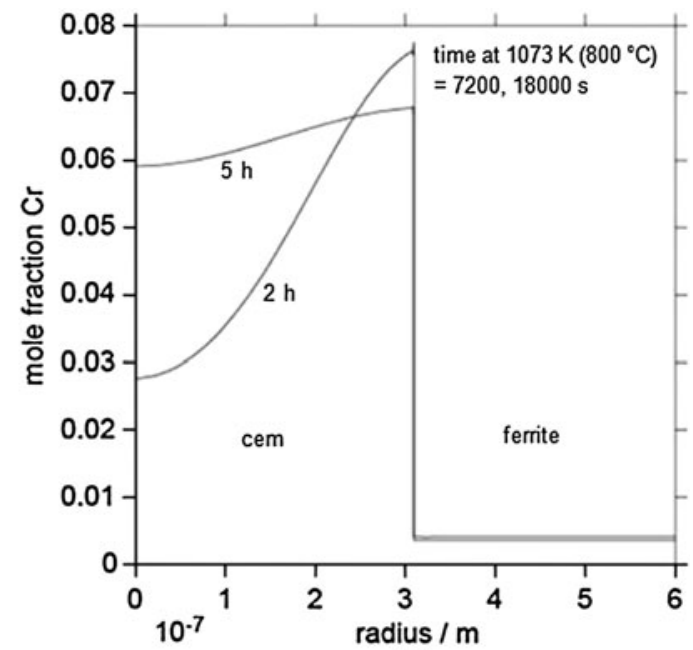

(b)

Fig. 11-Cr-composition profiles formed during annealing at $1073 \mathrm{~K}\left(800^{\circ} \mathrm{C}\right)$. (a) Mobilities of $\mathrm{Cr}$ according to MOBFE2, (b) Mobilities of Cr increased by a factor of 5 .

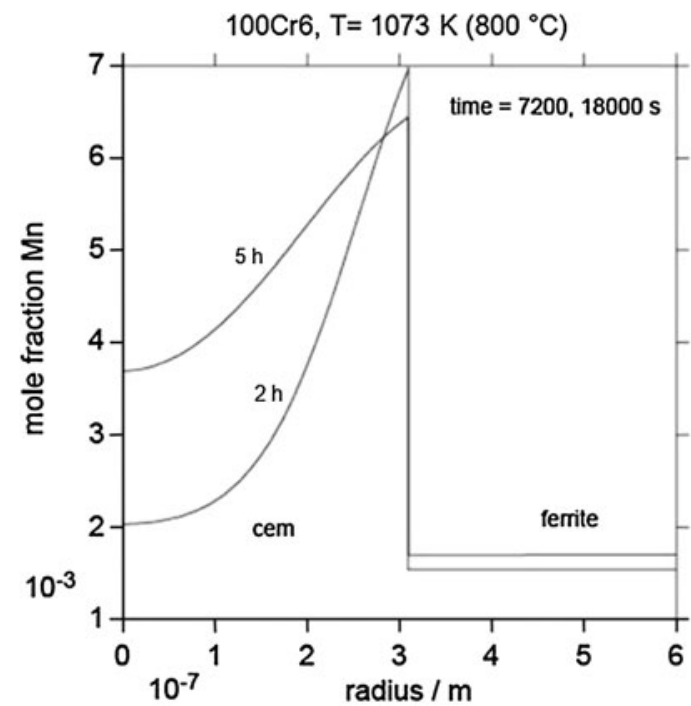

(a)

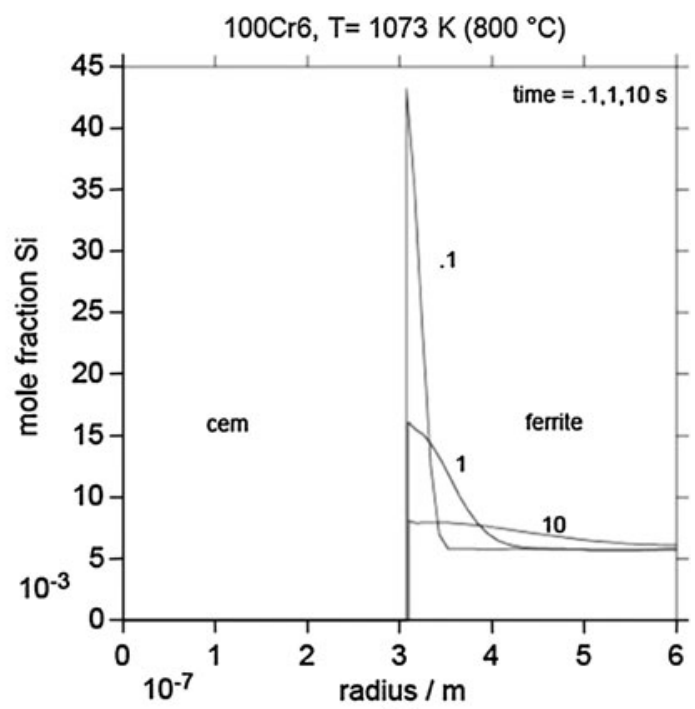

(b)

Fig. 12-Mn, Si-composition profiles formed during annealing at $1073 \mathrm{~K}\left(800^{\circ} \mathrm{C}\right)$ (Mobilities of $\mathrm{Cr}, \mathrm{Mn}, \mathrm{Si}$ increased by a factor of 5$)(a, b)$. 


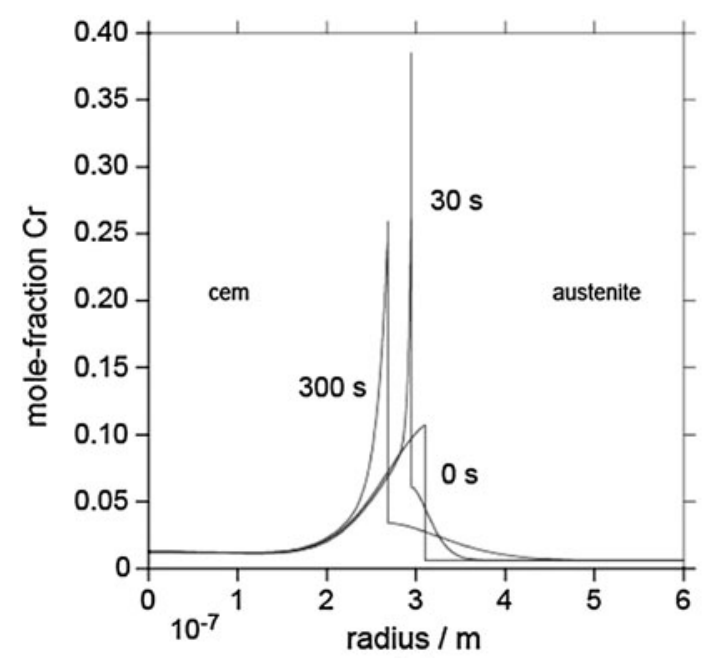

(a)

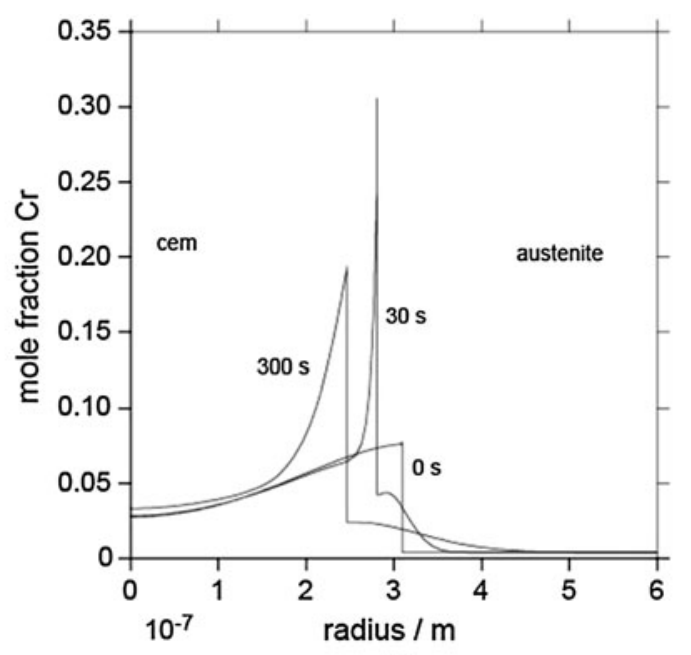

(b)

Fig. 13 - Composition profiles during austenitization at $1123 \mathrm{~K}\left(850^{\circ} \mathrm{C}\right)$. (a) Mobilities of $\mathrm{Cr}$, Mn, Si according to MOBFE2, (b) Mobilities of $\mathrm{Cr}, \mathrm{Mn}, \mathrm{Si}$ increased by a factor of 5 .

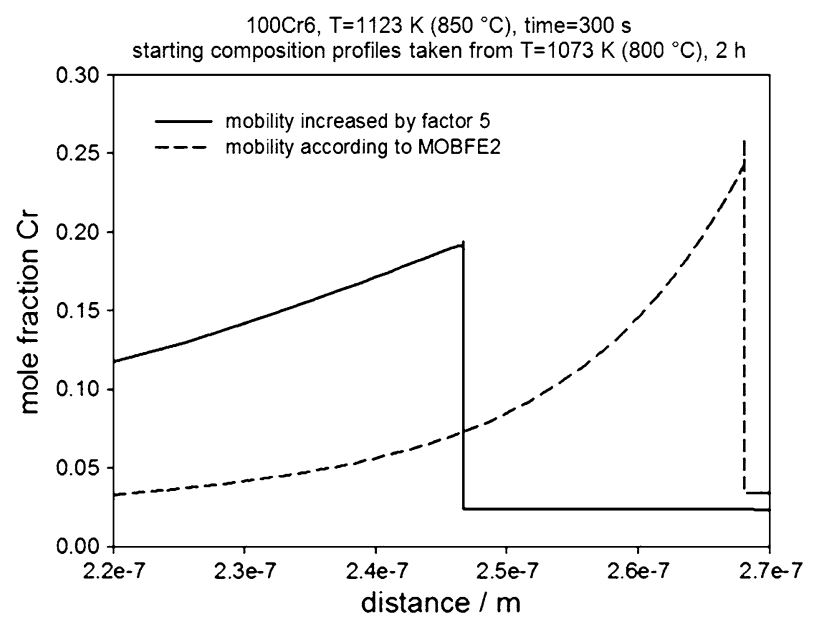

Fig. 14-Blow-up of the $\mathrm{Cr}$ concentration profiles in Fig. 13, temperature $1123 \mathrm{~K}\left(850^{\circ} \mathrm{C}\right)$, time $300 \mathrm{~s}$. The scaling of the $x$-axis has been selected similar to that of the experimental results in Fig. 8(a).

$d=0.49 \mu \mathrm{m}$. The shrinkage of cementite sets $\mathrm{Mn}, \mathrm{Cr}$, and $\mathrm{C}$ free for dissolution in austenite. Both, our current APT observations (see Figure 8) and the corresponding DICTRA calculations (see Figure 13) clearly reveal a gradual chemical gradient of $\mathrm{Cr}$ inside the spheroidized carbides. $\mathrm{Cr}$ exhibits a maximum concentration at the surface of spheroidized carbides and decreases gradually from the particle surface towards its core. The calculated results indicate a minimum concentration of $\mathrm{Cr}$ in the core region of the spheroidized carbides down to a level of about 2 at. pct.

The subsequent treatment at $773 \mathrm{~K}\left(500{ }^{\circ} \mathrm{C}\right)$ leads to the growth of cementite according to the NPLE regime. The $\mathrm{Cr}$ concentration in ferrite corresponds to that of austenite at $1123 \mathrm{~K}\left(850^{\circ} \mathrm{C}\right)$. Close to the interface ferr/ cem the $\mathrm{Cr}$ concentration is about $x_{\mathrm{Cr}}^{\alpha}=0.024$, and the $\mathrm{C}$-concentration is $x_{\mathrm{C}}^{\alpha}=0.029$. Cementite will thus grow with a $\mathrm{Cr}$ u-fraction of $u_{\mathrm{Cr}}^{\mathrm{cem}}=0.0247$. The mole fraction of $\mathrm{Cr}$ measured in cementite is then $x_{\mathrm{Cr}}^{\mathrm{cem}}=x_{\mathrm{Cr}}^{\mathrm{cem}} \cdot 0.75=0.0185$. This is in accordance with the result in Figure 8.

\section{CONCLUSIONS}

In this work, spheroidized carbides in a high carbon bearing steel $100 \mathrm{Cr} 6$ were characterized with respect to their morphology, phase fraction, size distribution, crystallography, and kinetics of carbide dissolution behavior, applying SEM, TEM, and APT. The spheroidized carbide dissolution kinetics was analyzed using dilatometry. The chemical gradient of $\mathrm{C}, \mathrm{Cr}, \mathrm{Mn}$, and $\mathrm{Si}$ within spheroidized carbides, cementite, bainitic ferrite matrix, and the atom partitioning behaviors across phase boundaries were investigated at the atomic scale. By using the APT technique, we gained deeper insights into the nature of spheroidized carbides and transformation dynamics of carbon, chromium, and other alloy element atoms. The results can be summarized as follows:

1. 14 vol pet spheroidized carbides $(\mathrm{Fe}, \mathrm{Cr})_{3} \mathrm{C}$ are formed during soft annealing and 3 vol pct remain after dissolution into the austenite matrix during austenitization at $1123 \mathrm{~K}\left(850{ }^{\circ} \mathrm{C}\right)$ for 300 seconds.

2. The fast-diffusing element $\mathrm{C}$ is distributed homogeneously in both, the partially dissolved spheroidized carbides and in the cementite formed during the $773 \mathrm{~K}\left(500{ }^{\circ} \mathrm{C}\right)$ bainite stage.

3. $\mathrm{Cr}$ exhibits a gradual chemical gradient inside the spheroidized carbides. The $\mathrm{Cr}$ concentration exhibits a maximum value (16 at. pct) at the surface of the spheroidized carbides, gradually decreasing from surface to the core down to a level of about 2 at. pet.

4. Spheroidized carbides remaining partially dissolved after austenitization at $1123 \mathrm{~K}\left(850^{\circ} \mathrm{C}\right)$ may exist as nucleation site for lower temperature cementite 
within bainite. The latter grows with a relatively lower $\mathrm{Cr}$ concentration (2 at. pct) during $773 \mathrm{~K}$ $\left(500{ }^{\circ} \mathrm{C}\right)$ bainitizing.

5. Si exhibits a large enrichment at the growth front of cementite, which hinders the further coarsening of the cementite particles.

6. DICTRA calculations reveal that cementite precipitation at $773 \mathrm{~K}\left(500{ }^{\circ} \mathrm{C}\right)$ occurs under NPLE condition mode and show good agreement with the experimental compositional distributions detected by APT. Good agreement with the experimental compositional distributions detected by APT is obtained by an increase of mobility of the substitutional elements in cementite by a factor of five, compared to the mobility in the database MOBFE2.

\section{ACKNOWLEDGMENTS}

This work has been performed within the Interdisciplinary Centre for Advanced Materials Simulation (ICAMS) at Ruhr University Bochum. ICAMS gratefully acknowledges funding from ThyssenKrupp Steel Europe AG, Bayer Material Science AG, Salzgitter Mannesmann Forschung GmbH, Robert Bosch $\mathrm{GmbH}$, Benteler Steel/tube Management GmbH, Bayer Technology Services $\mathrm{GmbH}$ and the state of North RhineWestphalia as well as the European Commission in the framework of the European Regional Development Fund (ERDF). Authors would like to express their many thanks to Dr. Christoph Somsen in Ruhr-University Bochum for his support of TEM experiment.

\section{REFERENCES}

1. N. Min, W. Li, H. Li, and X. Jin: J. Mater. Sci. Technol., 2010, vol. 26, pp. 776-82.
2. K. Tanaka, H. Ikehata, K. Nakanishi, and T. Nishikawa: Metall. Mater. Trans. A, 2008, vol. 39A, pp. 1248-57.

3. Y. Takahama, M.J. Santofimia, M.G. Mecozzi, L. Zhao, and J. Sietsma: Acta Mater., 2012, vol. 60, pp. 2916-26.

4. D.V. Shtansky and G. Inden: Acta Mater., 1997, vol. 45, pp. 286178.

5. A. Schneider and G. Inden: Acta Mater., 2005, vol. 53, pp. 51931.

6. G. Ghosh and G.B. Olson: Acta Mater., 2002, vol. 50, pp. 20992119.

7. G. Miyamoto and T. Furuhara: ISIJ Meet., 2008.

8. G. Miyamoto, J.C. Oh, K. Hono, T. Furuhara, and T. Maki: Acta Mater., 2007, vol. 55, pp. 5027-38.

9. S. Ghosh: Scripta Mater., 2012, vol. 63, pp. 273-76.

10. T. Sakuma, N. Watanabe, and T. Nishizawa: Trans. JIM, 1980, vol. 21, pp. 159-68.

11. J. Agren, H. Abe, T. Suzuki, and Y. Sakuma: Metall. Trans. A, 1985, vol. 17A, pp. 617-20.

12. P. Jacques, E. Girault, T. Catlin, N. Geerlofs, T. Kop, S. van der Zwaag, and F. Delannay: Mater. Sci. Eng. A, 1999, vols. 273-275, pp. $475-79$.

13. E. Kozeschnik and H.K.D.H. Bhadeshia: Mater. Sci. Technol., 2008 , vol. 24 , pp. $343-47$

14. Z.-K. Liu, L. Höglund, B. Jönsson, and J. Ågren: Metall. Trans. A., 1990, vol. 22A, pp. $1745-52$.

15. H.K.D.H. Bhadeshia: Prog. Mater Sci., 2011, vol. 57, pp. 268435.

16. J.-B. Seol, D. Raabe, P. Choi, Y.-R. Im, and C.-G. Park: Acta Mater., 2012, vol. 60, pp. 6183-99.

17. E.A. Marquis, P.-P. Choi, F. Danoix, K. Kruska, S. Lozano-Perez, D. Ponge, D. Raabe, and C.A. Williams: Microsc. Today, 2012, vol. 20 (4), pp. 44-48.

18. Thermo-Calc software AB, Stockholm, Sweden; http://www. thermocalc.com

19. N. Saunders and A.P. Miodownik: Pergamon Materials Science, Elsevier Science, Oxford, 1998, vol. 1.

20. A. Borgenstamm, A. Engström, L. Höglund, and J. Ågren: $J$. Phase Equilib., 2000, vol. 21, pp. 269-80.

21. A. Schneider and G. Inden: Continuum Scale Simulation of Engineering Materials, Wiley-VCH, Weinheim, 2004.

22. G. Inden: Materials Issues for Generation IV Systems, Springer, Berlin, 2008.

23. W. Song, J. von Appen, P. Choi, R. Dronskowski, D. Raabe, and W. Bleck: Acta Mater., 2013. DOI:10.1016/j.actamat.2013. 08.051 .

24. A.T.W. Barrow and P.E.J. Rivera-Díaz-del-Castillo: Acta Mater., 2011, vol. 59, pp. 7155-67. 